\title{
Anatomical, clinical and surgical aspects of the posterior
} cornea

\section{Aspectos anatómicos, clínicos y quirúrgicos de la córnea posterior}

\author{
Carlos E. de la Torre-González ${ }^{1,2 *}$, Ariadna E. García-Castro² and Carmen L. Pérez-Julca²
}

${ }^{1}$ Cornea clinic, Hospital Juárez de México, Secretaria de Salud; ${ }^{2}$ Cornea and refractive surgery fellow, Universidad Nacional Autónoma de México, Hospital Juárez de México. Mexico City, Mexico

\begin{abstract}
The advance in the knowledge of corneal ultrastructure that previously would have been considered a curiosity or just intellectual data, today is essential for the clinician. The purpose of this review is to address the elements that, based on the authors' criteria, are more relevant to the "new" anatomical (histological) aspects of the cornea and how they affect the relatively new surgical techniques, emphasizing the role of "Dua's layer." The composition of the corneal stroma also varies according to depth. Corneal tissue obtainment varies according to the dissection technique used, although it is true that in pneumodissection pre-descemet stromal remnants remain, but they do not constitute a new anatomical layer. The differences in hydration and disposition between the corneal lamellae cause the cornea to behave differently depending on the dissection plane. Age-related changes facilitate the procurement of the descemet-endothelium membrane, as it becomes thicker and easier to manipulate.
\end{abstract}

Key words: Corneal lamellar graft. DSAEK. DMEK. DALK. Corneal anatomy. Dua's layer.

\section{Resumen}

El avance en el conocimiento de la ultraestructura de la córnea, que anteriormente podía representar una curiosidad o un dato intelectual para presumir, actualmente es imprescindible para el clínico. Esta revisión tiene por objetivo mencionar los elementos que a juicio de los autores son más relevantes de los aspectos anatómicos (histológicos) «nuevos» de la córnea y como impactan en las también relativamente nuevas técnicas quirúrgicas, enfatizando el papel que tiene la «capa de Dua». La composición del estroma corneal también varía de acuerdo a la profundidad. La obtención del tejido corneal varía de acuerdo a la técnica de disección empleada, si bien es cierto que en la pneumodisección quedan remanentes estromales predesceméticos, estos no constituyen una nueva capa anatómicamente. Las diferencias de hidratación y unión entre las láminas corneales hacen que la córnea se comporte de manera distinta dependiendo del plano de disección. Los cambios que suceden con la edad facilitan la procuración de la membrana de Descemet-endotelio al hacerse más gruesa y fácil de manipular.

Palabras clave: Injerto laminar corneal. DSAEK. DMEK. DALK. Anatomía corneal. Capa de Dua.

\section{Correspondence:}

${ }^{*}$ Carlos E. de la Torre-González

Hospital Español, Torre antigua de consultorios

Av Ejército Nacional 613 int. 601

Col. Granada, Del. Miguel Hidalgo Date of reception: 15-01-2018

C.P. 11560, Mexico City, México_ Date of acceptance: 18-04-2018

E-mail: delatorre_cornea@yahoo.com.mx DOI: 10.24875/RMOE.M18000029 Co SA de CV. This is an Open Access article under the CC BY-NC-ND license (http://creativecommons.org/licenses/by-nc-nd/4.0/). 


\section{Introduction}

Due to the great relevance of the cornea, not only as the most important optical element of the eye but also due to the wide range of pathologies to which it is susceptible from birth to old age, and even more so by the possibility of undertaking several treatments, from different types of laser to chemical procedures such as chelation, or its complete or partial replacement through penetrating and lamellar transplants, among others, the study of its physiology and, in particular, of its anatomy is subject of great interest in the clinical and basic areas. The advance in the knowledge of corneal ultrastructure that previously could represent a curiosity or just intellectual data is now essential for the clinician. The objective of this review is to cover the elements that, in the opinion of the authors, are more relevant to the "new" anatomical (histological) aspects of the cornea and how they influence the relatively new surgical techniques, emphasizing the role of «Dua's layer» and the controversy it created in different national and international forums. In addition, we present several clinical cases correlating visual with clinical, test and histology images.

\section{Anatomy and corneal histology applied to the clinic}

The cornea consists of five layers: epithelium, Bowman's layer, stroma, Descemet's membrane and endothelium. It is not the aim of this work to address the aspects of the anterior cornea (epithelium and Bowman's layer), although its relevance should not be ignored given the high impact that the air-tear film interface has on the optic system.

As we know, corneal transparency depends on the degree of spatial regularity in the arrangement of the fibers, forming sheets that run in an organized orthogonal manner and that constitute the "skeleton" of the cornea. In the center of the cornea the lamella are scarce, around 300 , while in the periphery they increase in the proximity of the limbus to approximately 500 . The lamellae in the posterior portion of the cornea are continuous from limbus to limbus and up to the corneoscleral junction, showing a circular arrangement in this site called by Radner ${ }^{1}$ the "corneal circular ligament" (by electron scanning microscopy). The lamellae in the posterior portion of the cornea are more organized and hydrated $^{2}$, and they have a lower refractive index compared to the anterior cornea. Also, their arrangement is parallel to the posterior corneal curvature and they are thicker and wider (100 to $200 \mu \mathrm{m}$ in length and 1 to 2.5 in thickness vs. 0.5 and 0.2 to $1.2 \mu \mathrm{m}$, respectively). These histological differences regarding organization and thickness allow an easier dissection of the posterior stroma compared to the anterior stroma, with manual techniques or using various substances such as air or solutions that help finding a dissection plane. Despite this relative ease, it is clear that it is not exempt from the resistance given by the bonds between the Jamella and the extracellular matrix proteins, such as proteoglycans $^{3}$. It is important to point out that, unlike the lamella in the posterior stroma with a parallel disposition to the posterior surface, the lamella in the anterior stroma are interweaved, they travel antero-posterior, and through other lamella in their trajectory until they reach their destiny. In some cases, this arrangement may be clinically observed after fluorescein instillation.

The composition of the corneal stroma also varies according to depth. The glycosaminoglycans of the corneal stroma are keratan sulfate and chondroitin/ dermatan sulfate. The first is the most abundant and has the greatest affinity for water, and it is found in greater quantity in the posterior stroma, so the anterior stroma is more compact while the posterior portion is more prone to edema ${ }^{4}$.

In 2002, Anwar published an article describing the way to "expose the Descemet membrane" by using a large bubble ${ }^{5}$, which, according to the author, separated the Descemet's membrane from the more posterior stroma, describing the "type 1 bubble". Other authors have reported similar techniques using air, viscoelastic or saline for anterior lamellar transplants $\mathrm{s}^{6-8}$. However, this is not completely true and has led to confusion, as we will explain later.

The revolution of anterior and posterior lamellar grafts started after the establishment of a controlled and reproducible form of corneal dissection. Without a doubt, although after much debate and thanks to the meta-analyses that have been carried out, lamellar graft transplant techniques are the procedure of choice in the treatment of anterior and posterior corneal pathology. The most common modalities are deep anterior lamellar keratoplasty (DALK) (Fig. 1) for anterior pathology, and Descemet's stripping automated endothelial keratoplasty (DSAEK) (Fig. 2) as well as Descemet's membrane endothelial keratoplasty (DMEK) for posterior corneal pathology (Fig. 3). In both techniques, it is important to separate the Descemet membrane from the posterior stroma, both in the donor and in the recipient, and then adding the healthy part that the recipient is missing, achieving advantages that penetrating keratoplasty cannot overcome $e^{9-11}$. 


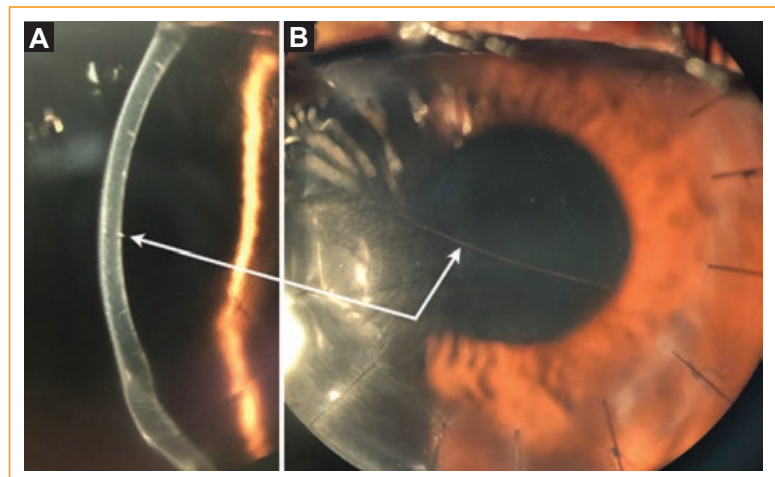

Figure 1. A: Deep anterior lamellar keratoplasty without evidence of an interface. B: Direct illumination showing a Descemet membrane fold in the recipient.

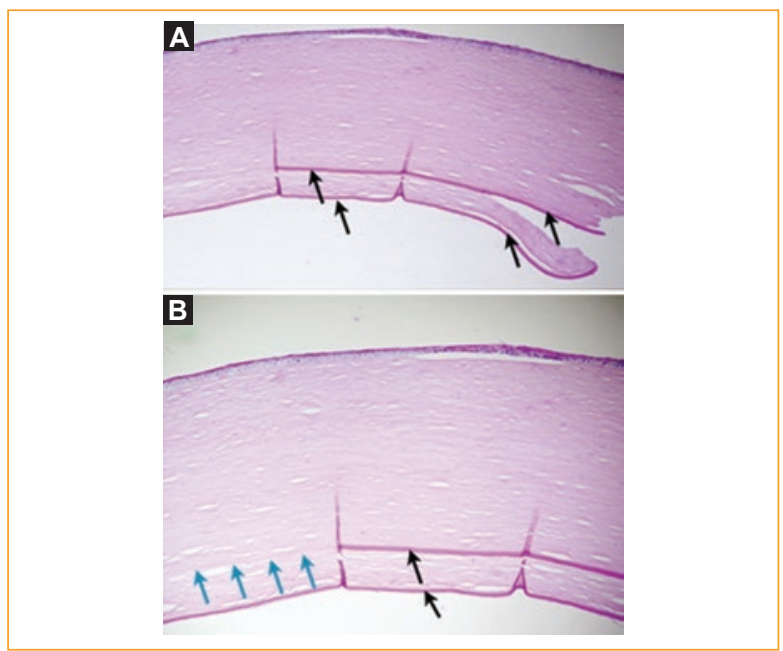

Figure 2. A: High-power photomicrograph showing lamellae of the deep stroma and Descemet's membrane; double Descemet's membrane in the periphery (black arrows) (Periodic acid- Schiff (PAS), original magnification 40x). B: Interface line between the receptor and donor stroma (blue arrows).

In 2003, Dua, et al. ${ }^{12}$, based on their extensive experience with the DALK technique and their great observation capacity, postulated the existence of a new layer called "Dua's layer" in their work "Redefining human corneal anatomy" when noticing that after obtaining a type 1 bubble, a plane of cleavage is achieved in the pre-Descemet portion of the stroma, which measures on average $10.15 \pm 3.6 \mu \mathrm{m}$ before reaching the Descemet membrane. They emphasize that the dissection does not really occur between Descemet's membrane and the stroma, as previously thought, and it is even

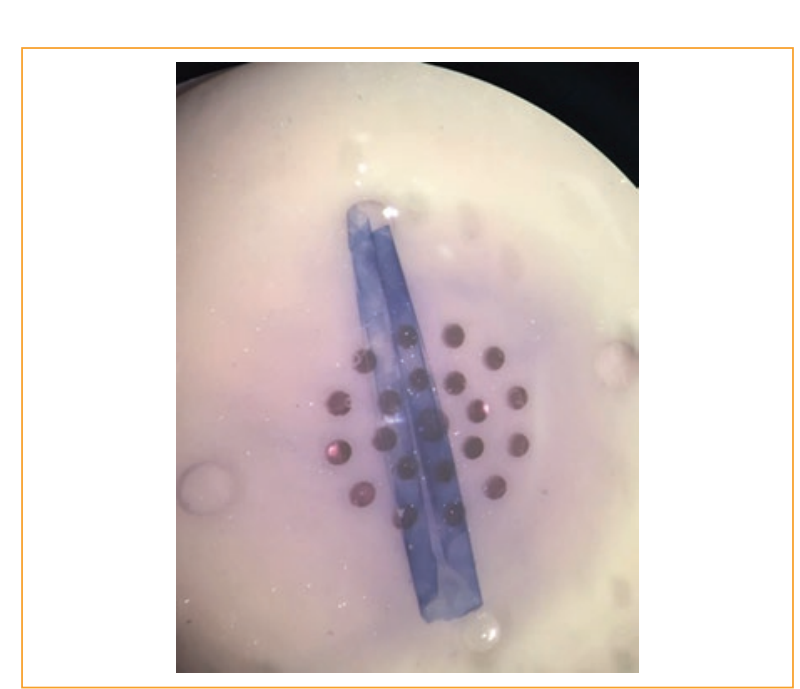

Figure 3. Scroll Descemet membrane formation with endothelium in the outer aspect for Descemet membrane endothelial keratoplasty (trypan blue staining).

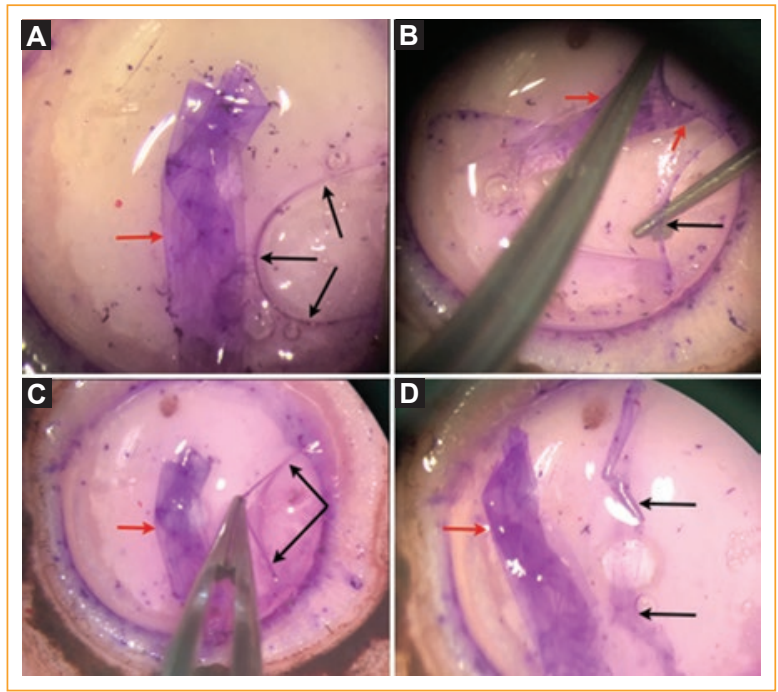

Figure 4. A: donor's descemetorhexis stained with trypan blue (red arrow), with an air bubble in the deep stroma (black arrows) (A). Endothelium and Descemet (red arrows) with cannula (B) and clamp (C) in the space formed in the posterior stroma, showing the so-called "Dua's layer». D: endothelium and Descemet (red arrow) dissection and deep pre-Descemet stroma, "Dua's layer".

possible to remove Descemet's membrane without breaking the large air bubble contained in this space in the deepest stroma. These findings are indisputable and replicable, as shown in figure 4 , in sclerocorneal buttons not suitable for clinical use, dissected by the authors of this review. It is clear, then, that there is a 
plane of cleavage in the deep stroma that is also visible by optical coherence tomography (Fig. 5), although this really cannot be considered as a new layer nor redefines corneal anatomy, as discussed in the editorial published in the same journal shortly after ${ }^{13}$.

In order to corroborate Dua's findings, a multicenter study was carried out to redefine the structure of the posterior stroma ${ }^{14}$. By light microscopy, as expected, no line of demarcation was observed in the posterior stroma and keratocytes were observed at different distances from the Descemet membrane, unlike the postulate of an acellular Dua's layer. Transmission microscopy confirmed a variable distance between the Descemet and the keratocytes, the latter found as close as $1.5 \mu \mathrm{m}$ in the center of the cornea, refuting the existence of a posterior layer of acellular stroma. At the Descemet-stroma interface, an intermediate layer of 0.5 to $1 \mu \mathrm{m}$ was found, formed by irregularly arranged collagen, with fibers of smaller diameter (21.5 to $2.1 \mathrm{~nm}$ ), not organized in bundles like the Bowman layer, and strongly positive for type III collagen by immunofluorescence.

Although it is true that there are different modes of donor procurement ${ }^{15}$, either with manual techniques ${ }^{16}$, pneumodissection or viscodissection (Fig. 6), the endothelial cell loss observed after the preparation of the donor in the DMEK technique is from 2 to $8 \%{ }^{17,18}$. While the reports at 6 months after grafting indicate that the loss (when it is reported) is high and ranges from 19 to $44 \%{ }^{19,20}$, depending on the author, and tends to stabilize after the first year. It is important to mention that, although it would be desirable to perform two donation procedures from a single cornea to compensate the shortage of donor tissue, this could be counterproductive at least in places where Descemet's procurement is not very common and even in places accustomed to these procedures in which tissue loss is reported during handling in almost a quarter of the cases ${ }^{17,21}$. Of the techniques used, it seems that manual dissection with the Scuba technique is more reproducible and allows the procurement of larger areas of Descemet membrane. One strategy that decreases loss during preparation and facilitates tissue dissection is the use of corneas from aged donors ${ }^{22}$, whose clinical implications are not the subject of this review ${ }^{23-25}$.

The posterior cornea shows changes with age, not only due to the physiological endothelial loss calculated in $0.6 \%$ per year ${ }^{26}$, but also due to the changes that occur in the Descemet membrane, whose description dates back to 1758. The first collagen lamellae of the Descemet membrane are secreted in the uterus by the endothelial cells at 4 months of gestation, which

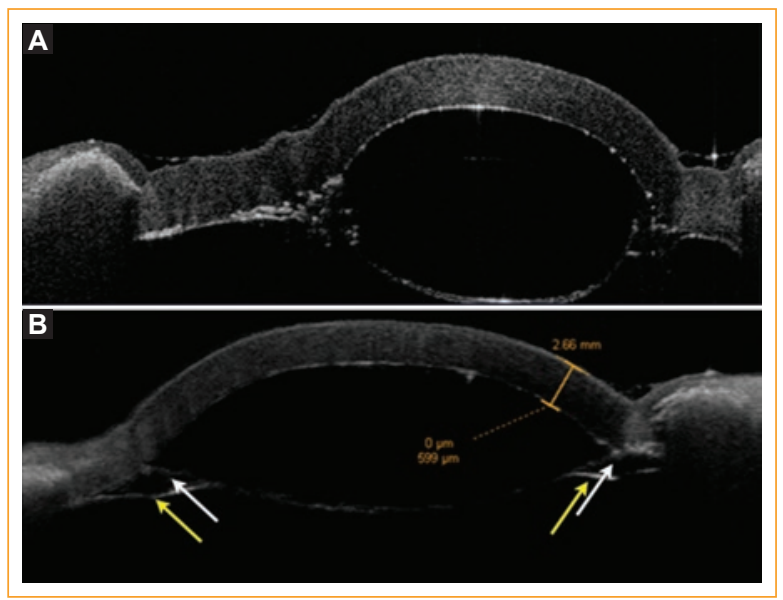

Figure 5. Optical coherence tomography A: small, well-defined type 1 bubble, with pneumodissection of stroma and Descemet. B: Pneumodissection shows separation of the endothelium and Descemet (yellow arrow) from the pre-Descemet stroma (white arrow).

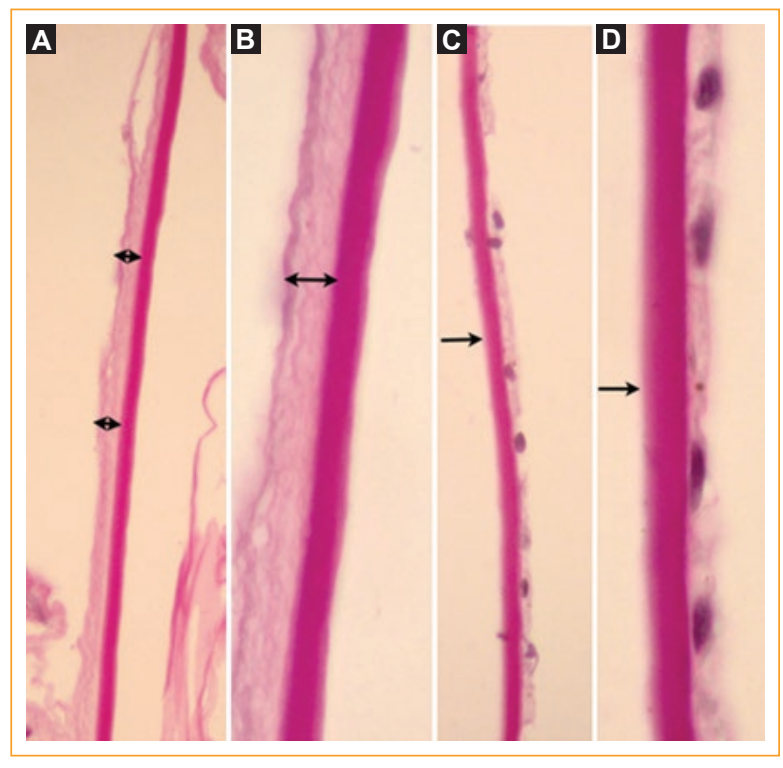

Figure 6. A and B: high-magnification photomicrography of corneal tissue obtained by pneumodissection showing deep stroma lamellae and Descemet membrane, without endothelial cells (PAS, original amplification 40x and 100x). C and D: tissue obtained without pneumodissection with Scuba manual technique in which only Descemet membrane and endothelium are observed without the presence of pre-Descemet stromal collagen sheets (PAS, original amplification 40x and 100x).

condense forming a band at 8 months of gestational age. At birth, the anterior portion of the Descemet membrane is the only one present, with a thickness of $3 \mu \mathrm{m}$. 
After birth, a second posterior portion of the membrane is produced, which is homogeneous, unlike the previous one, and it thickens with age, although the degree of thickening is very variable among individuals, as observed in physiological endothelial cell loss. As a consequence, this parameter is not useful to estimate a person's age, although as an individual ages, the membrane will be thicker and the endothelial cell count will also be lower ${ }^{27}$. This increase in Descemet membrane thickness with age allows an easier manipulation in older donors and in some other conditions of thickening, like patients with Fuchs' dystrophy, in whom descemetorhexis is very simple.

\section{Conclusions}

Corneal tissue procurement varies according to the dissection technique used, and although it is true that there are pre-Descemet stromal remnants in pneumodissection, they do not constitute a new anatomical layer. The differences in hydration and junctions between the corneal lamellae cause the cornea to behave differently depending on the dissection plane. The changes that occur with age facilitate Descemet membrane-endothelium procurement, as it becomes thicker and easier to manipulate. It is important for the cornea surgeon to consider these anatomical features to understand the behavior of the tissue in his surgical practice.

\section{Acknowledgements}

The authors wish to thank the collaboration of the Pathology Department of the Asociación para Evitar la Ceguera en México and in particular to Dr. Abelardo Rodríguez Reyes for his valuable help in processing and analyzing histological sections.

\section{References}

1. Radner W, Zehetmayer M, Aufreiter R, Mallinger R. Interlacing and cross-angle distribution of collagen lamellae in the human cornea. Cornea. 1998;17(5):537-43.

2. Freund DE, McCally RL, Farrell RA, Cristol SM, L'Hernault NL, Edelhauser HF. Ultrastructure in anterior and posterior stroma of perfused human and rabbit corneas. Relation to transparency. Invest Ophthalmol Vis Sci. 1995;36(8):1508-23.

3. Meek KM, Blamires T, Elliott GF, Gyi TJ, Nave C. The organisation of collagen fibrils in the human corneal stroma: a synchrotron X-ray diffraction study. Curr Eye Res. 1987;6(7):841-6.
4. Bettelheim FA, Plessy B. The hydration of proteoglycans of bovine cornea. Biochim Biophys Acta. 1975;381(1):203-14.

5. Anwar M, Teichmann KD. Big-bubble technique to bare Descemet's membrane in anterior lamellar keratoplasty. J Cataract Refract Surg. 2002;28(3):398-403.

6. Archila EA. Deep lamellar keratoplasty dissection of host tissue with intrastromal air injection. Cornea. 1984;3(3):217-8.

7. Loewenstein A, Lazar M. Deep lamellar keratoplasty with complete removal of pathological stroma for vision improvement. $\mathrm{Br} \mathrm{J}$ Ophthalmol. 1998;82(2):205

8. Sugita J, Kondo J. Deep lamellar keratoplasty with complete removal of pathological stroma for vision improvement. $\mathrm{Br} J$ Ophthalmol. 1997;81(3):184-8.

9. Shimazaki J, Ishii N, Shinzawa M, Yamaguchi T, Shimazaki-Den S, Satake Y. How Much Progress Has Been Made in Corneal Transplantation? Cornea. 2015;34 Suppl 11:S105-11.

10. Nanavaty MA, Wang X, Shortt AJ. Endothelial keratoplasty versus penetrating keratoplasty for Fuchs endothelial dystrophy. Cochrane Database Syst Rev. 2014(2):CD008420.

11. Keane M, Coster D, Ziaei M, Williams K. Deep anterior lamellar keratoplasty versus penetrating keratoplasty for treating keratoconus. Cochrane Database Syst Rev. 2014(7):CD009700.

12. Dua HS, Faraj LA, Said DG, Gray T, Lowe J. Human corneal anatomy redefined: a novel pre-Descemet's layer (Dua's layer). Ophthalmology. 2013;120(9):1778-85.

13. McKee HD, Irion LC, Carley FM, Brahma AK, Jafarinasab MR, Rahmati-Kamel M, et al. Re: Dua et al.: Human corneal anatomy redefined: a novel pre-Descemet layer (Dua's layer) (Ophthalmology 2013;120:177885). Ophthalmology. 2014;121(5):e24-5.

14. Schlotzer-Schrehardt U, Bachmann BO, Tourtas T, Torricelli AA, Singh A, Gonzalez S, et al. Ultrastructure of the posterior corneal stroma. Ophthalmology. 2015;122(4):693-9.

15. Birbal RS, Sikder S, Lie JT, Groeneveld-van Beek EA, Oellerich S, Melles GRJ. Donor Tissue Preparation for Descemet Membrane Endothelial Keratoplasty: An Updated Review. Cornea. 2018;37(1):728-35.

16. Melles GR, Lander F, Rietveld FJ. Transplantation of Descemet's membrane carrying viable endothelium through a small scleral incision. Cornea. 2002;21(4):415-8.

17. Krabcova I, Studeny P, Jirsova K. Endothelial quality of pre-cut posterior corneal lamellae for Descemet membrane endothelial keratoplasty with a stromal rim (DMEK-S): two-year outcome of manual preparation in an ocular tissue bank. Cell Tissue Bank. 2013;14(2):325-31.

18. Ignacio TS, Nguyen TT, Sarayba MA, Sweet PM, Piovanetti O, Chuck RS, et al. A technique to harvest Descemet's membrane with viable endothelial cells for selective transplantation. Am J Ophthalmol. 2005; 139(2): 325-30.

19. Gorovoy IR, Gorovoy MS. Descemet membrane endothelial keratoplasty postoperative year 1 endothelial cell counts. Am J Ophthalmol. 2015;159(3):597-600 e2.

20. Studeny P, Farkas A, Vokrojova M, Liskova P, Jirsova K. Descemet membrane endothelial keratoplasty with a stromal rim (DMEK-S). $\mathrm{Br} \mathrm{J}$ Ophthalmol. 2010;94(7):909-14.

21. Tausif HN, Johnson L, Titus M, Mavin K, Chandrasekaran N, Woodward MA, et al. Corneal donor tissue preparation for Descemet's membrane endothelial keratoplasty. J Vis Exp. 2014(91):51919.

22. Heinzelmann S, Huther S, Bohringer D, Eberwein $P$, Reinhard T, Maier $P$. Influence of donor characteristics on descemet membrane endothelial keratoplasty. Cornea. 2014:33(6):644-8.

23. Venzano D, Pagani P, Randazzo N, Cabiddu F, Traverso CE. Descemet membrane air-bubble separation in donor corneas. J Cataract Refract Surg. 2010;36(12):2022-7.

24. Zarei-Ghanavati S, Zarei-Ghanavati M, Ramirez-Miranda A. Air-assisted donor preparation for DMEK. J Cataract Refract Surg. 2011;37(7):1372; author reply

25. Zarei-Ghanavati S, Khakshoor H, Zarei-Ghanavati M. Reverse big bubble: a new technique for preparing donor tissue of Descemet membrane endothelial keratoplasty. Br J Ophthalmol. 2010;94(8):1110-1.

26. Bourne WM, Nelson LR, Hodge DO. Central corneal endothelial cell changes over a ten-year period. Invest Ophthalmol Vis Sci. 1997;38(3): 779-82.

27. Johnson DH, Bourne WM, Campbell RJ. The ultrastructure of Descemet's membrane. II. Aphakic bullous keratopathy. Arch Ophthalmol. 1982; 100(12):1948-51. 